\title{
DNA ploidy as an independent prognostic factor: 10-year results in a group of patients surgically treated for squamous cell lung cancer
}

\author{
Ocena ploidii jako niezależnego czynnika rokowniczego u chorych na \\ raka płaskonabłonkowego płuca leczonych chirurgicznie na podstawie \\ 10-letnich obserwacji
}

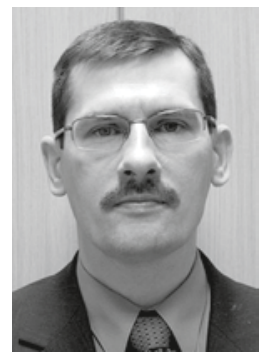

Mariusz Kasprzyk ${ }^{1}$, Wojciech Dyszkiewicz ${ }^{1}$, Magdalena Roszak ${ }^{2}$, Rafał Rutkowski ${ }^{3}$, Cezary Piwkowski ${ }^{1}$, Paweł Zieliński $^{1}$,
Krystian Pawlak ${ }^{1}$

${ }^{1}$ Department of Thoracic Surgery, Poznan University of Medical Sciences

2Department of Computer Science and Statistics, Poznan University of Medical Sciences

${ }^{3}$ Chair of Biology and Environment Protection, Poznan University of Medical Sciences

Kardiochirurgia i Torakochirurgia Polska 2012; 3: 327-333

\begin{abstract}
Background: The biological variability of lung cancer is one of the causes of the unpredictable clinical outcome of the disease. Many investigators have devoted a lot of effort to finding molecular and biochemical prognostic factors that may prove helpful in the qualification of patients for postoperative chemotherapy. Notwithstanding various previous studies attempted to associate DNA quantification in cancer cells with the prognosis for lung cancer, there is a divergence of opinion about its value. The aim of the present study was to assess the impact of aneuploidy on late (10-year) survival in a group of patients treated surgically for squamous cell lung cancer. Material and methods: We analyzed a group of 110 patients surgically treated for squamous cell lung cancer between 1995 and 1997. The group consisted of 95 men and 15 women, aged between 34 and 77 years (the average age being 60). We performed lobectomy in 52 cases, pneumonectomy in 47 cases, and other resections in 11 patients. Most of the patients were in IB (35 cases), IIB (26 patients) and IIIA (22 cases) pathological stage of the disease. Paraffin-embedded pathological samples underwent a cytometric analysis to determine the DNA content in cancer cells. The DNA index was established in each specimen. A statistical analysis was performed using Statistica 10.0 and StatXact 8 software.

Results: DNA aneuploidy was found in $44.5 \%$ of cases. We did not find any relationship between ploidy and age, gender, TNM stage, T stage, $N$ stage or grading. The percentage of surgical procedures and adjuvant therapies in patients with aneuploid
\end{abstract}

\section{Streszczenie}

Wstęp: Duża zmienność biologiczna raka płuca powoduje, że mimo określonego typu histologicznego i stopnia zaawansowania raka wg klasyfikacji TNM przebieg choroby jest trudny do przewidzenia. Dlatego poszukuje się molekularnych i biochemicznych czynników mających znaczenie prognostyczne i pomocnych w kwalifikacji chorych do pooperacyjnej chemioterapii. Jednym z takich czynników mogą być zaburzenia zawartości DNA w komórkach nowotworowych, choć opinie na temat rokowniczego znaczenia ploidii są wśród badaczy podzielone. Celem pracy była ocena wpływu nieprawidłowej ilości DNA w komórkach raka na wyniki odległe (10-letnie) leczenia chirurgicznego raka płaskonabłonkowego płuca.

Materiat i metody: Analizie poddano grupę 110 chorych leczonych operacyjnie z powodu raka płaskonabłonkowego płuca w latach 1995-1997. W badanej grupie było 95 mężczyzn i 15 kobiet w wieku 34-77 lat (średnia 60 lat). U 52 chorych wykonano lobektomię, u 47 pneumonektomię, a u 11 inne resekcje. Większość chorych operowano w stadium IB (35 chorych), IIB (26 pacjentów) i IIIA (22 chorych). Badany materiał stanowity preparaty parafinowe, w których metodą cytometrii przepływowej zbadano zawartość DNA w komórkach raka. W każdym przypadku oznaczono indeks DNA, a ilość DNA w komórkach nowotworowych zilustrowano w postaci histogramów. Analizę statystyczną przeprowadzono przy użyciu program komputerowy Statistica 10.0 i oraz StatXact 8.

Wyniki: Odsetek przypadków aneuploidalnych (z nieprawidłową ilością DNA) wyniósł 44,5\%. Nie stwierdzono korelacji mię-

Address for correspondence: Mariusz Kasprzyk, Klinika Torakochirurgii UM w Poznaniu, 60-569 Poznań, ul. Szamarzewskiego 62, tel. +48 61665 43 49, 608487 497, Fax +48 61665 43 53, e-mail: kasprzykmariusz@hotmail.com 
and diploid tumors was similar. Overall survival rates at 3, 5 and 10 years were $46.5 \%, 30.2 \%$, and $30.2 \%$ for diploid patients and $25 \%, 22.2 \%$, and $13.9 \%$ for patients with aneuploid tumors, respectively. Significant differences dependent on ploidy were observed in 3- and 10-year survival rates. More patients with aneuploid cancers died from distant metastases (78\% of deaths), whereas local cancer recurrence was more frequent in patients with diploid tumors (32\% of deaths). Multivariate analysis revealed TNM stage, T stage and DNA ploidy as independent factors affecting survival.

Conclusions: Aneuploidy appears to be a significant independent prognostic factor in patients with squamous cell lung cancer and can be useful in the qualification of patients for adjuvant therapy after surgery.

Key words: lung cancer, prognostic factors, aneuploidy. dzy ploidią a: wiekiem, płcią, stopniem zaawansowania raka wg TNM, cechą T, cechą N i stopniem zróżnicowania raka. Nie stwierdzono również istotnych różnic między grupą aneuploidalną i diploidalną w rodzaju wykonywanych resekcji i liczbie chorych poddanych leczeniu uzupełniającemu. Odsetki przeżyć 3-, 5- i 10-letnich w przypadkach diploidalnych wyniosły odpowiednio: $46,5 \%, 30,2 \%$ i 30,2\%, a w grupie aneuploidalnej: $25 \%, 22,2 \%, 13,9 \%$ i były znamiennie niższe u chorych z guzem aneuploidalnym w 3- i 10-letnim okresie obserwacji. W grupie chorych z guzem aneuploidalnym istotnie częściej przyczyną zgonu były przerzuty odległe (78\% zgonów), a wśród chorych z rakiem diploidalnym wznowa miejscowa (32\% zgonów). W analizie wieloczynnikowej potwierdzono znamienny wpływ trzech czynników na przeżycie odległe: stopnia zaawansowania raka wg TNM, cechy T oraz ploidii.

Wnioski: U chorych na raka płaskonabłonkowego płuca aneuploidia jest niezależnym czynnikiem rokowniczym. Oznaczenie zawartości DNA w komórkach raka może być pomocne w kwalifikacji chorych do pooperacyjnej chemioterapii.

Słowa kluczowe: rak płuca, czynniki prognostyczne, aneuploidia.

\section{Material and methods}

The subject group consisted of 110 patients treated surgically for squamous cell lung cancer between 1995 and 1997 at the Department of Thoracic Surgery, University of Medical Sciences in Poznań. The group included 95 men and 15 women, aged between 24 and 77 years, the average age being 60 . In each case, squamous cell lung cancer was identified in the course of preoperative diagnostics or as a result of intraoperative pathology. Lobectomy was performed in 52 cases, pneumonectomy in 47 cases, bilobectomy in 7 cases, and wedge resection in 4 cases. The staging of cancer was assessed according to the $7^{\text {th }}$ edition of the TNM classification published in 2009 by the International Association for the Study of Lung Cancer (IASLC). Most patients were in the IB (35 cases), IIB (26 patients), and IIIA (22 cases) stage of the disease. The degree of differentiation of cancer cells was classified as G2 in 52 cases, G3 in 48 cases and $\mathrm{G} 1$ in 10 cases. Follow-up of patients treated surgically was performed through questionnaires mailed directly to the patients, follow-up examinations in the oncological and thoracic surgery outpatient clinic, and data acquired from family doctors. The analyzed material included histological specimens in the form of paraffin blocks. The DNA content in cancer cells underwent flow cytometric analysis. In order to prepare a cellular suspension for cytometric analysis, two 50- $\mu \mathrm{m}$ thick sections from two different areas of the tumor were sampled with a microtome from each paraffin block. The sections were then prepared in accordance with the modified Hedley's procedure [12]. The minced sections were deparaffinized by incubating with xylene and the sediment was hydrated through graded alcohols, incubated with a pepsin solution and passaged through a syringe to acquire a single-cell suspension. After incubation with RNase and propidium iodide, DNA content measurements were taken with an Ortho Cytoron Absolute flow cytometer. 
The results were analyzed using ModFit software. The DNA content in cancer cells was presented graphically as linear charts or histograms. The DNA index (the ratio of DNA content at the G0/G1 phase in the analyzed cells to the DNA content in model cells at the same phase of the cell cycle) was established in each specimen. The following ploidy assessment criteria were adopted for the interpretation of results: histograms with a single peak of cells at the GO/ G1 stage of the cell cycle were classified as diploid, while histograms with more than one separate peak of cells at the GO/G1 stage were classified as aneuploid.

A statistical analysis was performed using Statistica 10.0 and StatXact 8 software. The limiting value of the significance level $(p)$ was set at 0.05 . In order to define the relation between particular variables, Pearson's $\chi^{2}$ test, a $\chi^{2}$ test with Yates's correction for continuity, and Fisher-Freeman-Halton's test were used. A trend analysis for selected variables was performed with a chi-squared test. The significance of differences for two unrelated samples was analyzed with the Mann-Whitney test and Kruskal-Wallis test (for more than two samples). In the case of significant differences, appropriate multiple comparison tests were performed. Odds ratios were calculated for particular variables and a model of logistic regression for the indicated parameters was formed. A survival analysis in two (with the log rank test) and three subject groups was carried out experimentally.

\section{Results}

In the analyzed material ( $n=110)$, DNA-aneuploid tumors were found in $44.5 \%$ of cases (49 patients), while DNA-diploid tumors were found in $55.5 \%$ of cases (61 patients). All cases of aneuploidy were of a hyperploid nature, which means that the DNA content in cancer cells was larger than in the case of diploid tumors (DNA index $>1$ ).
These included four tumors classified as tetraploid (DNA index = 2). Hypoploidy (DNA index < 1) was not observed. The DNA index in aneuploid tumors ranged from 1.19 to 4.2. No significant age- or gender-related differences between the two groups of subjects were found. Among the 110 surgically treated subjects, 25 (22.7\%) showed metastases in regional lymph nodes (N1 and/or N2), including 11 cases $(22.2 \%)$ with aneuploid tumors and 14 cases $(22.7 \%)$ with diploid tumors $(p=0.957)$. The locoregional progression in both types of tumors was similar, while the proportion of particular stages according to the TNM classification was not significantly different in the subject groups (Tab. I). Both in the diploid and aneuploid cases, the surgical treatment was administered most frequently to patients at the IB stage (32.5\% of cases). No statistically significant differences related to the degree of cancer cell differentiation were observed between the two subject groups (Tab. I). Although aneuploid cancer patients were more often treated with pneumonectomy ( $49 \%$ of cases), while diploid cancer patients were more often treated with lobectomy (50.8\% of cases), the difference in the type of administered surgery was not statistically significant. 48 patients (43.9\%) were subjected to adjuvant oncological treatment (chemo- and/or radiotherapy). The ratio of patients in both groups subjected to the adjuvant therapy did not differ significantly (46.9\% in aneuploid cases and $41 \%$ in diploid cases).

There were no deaths in the perioperative period. The survival probability for $1,2,3,5$, and 10 years for the entire subject group was, respectively, $61 \%, 41 \%, 34 \%, 25 \%$, and $22 \%$. The 3-, 5-, and 10-year survival rates in the diploid cases were, respectively, $46.5 \%, 30.2 \%$, and $30.2 \%$, while in the aneuploid cases they were $25 \%, 22.2 \%$, and $13.9 \%$. The 3- and 10-year survival rates were significantly lower for aneuploid tumor patients $(p=0.048)$. Ploidy-related su-

Table I. Clinical data relating to patients with diploid and aneuploid tumors

\begin{tabular}{|c|c|c|c|}
\hline & Diploid tumors $(n=61)$ & Aneuploid tumors $(n=49)$ & Total $(n=110)$ \\
\hline Age in years & 34-77 (av. 60.2) & 42-75 (av. 59.5) & 34-77 (av. 59.8) \\
\hline \multicolumn{4}{|l|}{ Gender } \\
\hline Female/Male & $8 / 53$ & $7 / 42$ & $15(13.6 \%) / 95$ (86.4\%) \\
\hline \multicolumn{4}{|l|}{ TNM Classification } \\
\hline $\mathrm{IA}$ & 9 & 5 & $14(12.5 \%)$ \\
\hline IB & 20 & 15 & $35(32.5 \%)$ \\
\hline IIB & 13 & 13 & $26(23.7 \%)$ \\
\hline IIIA & 12 & 10 & $22(19 \%)$ \\
\hline IIIB & 7 & 6 & $13(12.3 \%)$ \\
\hline \multicolumn{4}{|l|}{ Grading } \\
\hline G1 & 6 & 4 & $10(9 \%)$ \\
\hline G2 & 29 & 23 & $52(48 \%)$ \\
\hline G3 & 26 & 22 & $48(43 \%)$ \\
\hline \multicolumn{4}{|l|}{ Type of surgery } \\
\hline pneumonectomy & 23 & 24 & $47(42.7 \%)$ \\
\hline lobectomy & 31 & 21 & $52(47.3 \%)$ \\
\hline bilobectomy & 5 & 2 & $7(6.4 \%)$ \\
\hline wedge resection & 2 & 2 & $4(3.6 \%)$ \\
\hline Postoperative chemo- and/or radiotherapy & 25 & 23 & $48(43.9 \%)$ \\
\hline
\end{tabular}


DNA ploidy as an independent prognostic factor: 10-year results in a group of patients surgically treated ...

rvival curves are presented in Fig. 1. The deaths reported after a minimum of 5 years after surgery concerned only patients with aneuploid tumors. In $62 \%$ of cases, the cause of death were distant metastases, while in $25.9 \%$ of cases it was local recurrence, and in $6.9 \%$ of cases the death was non-cancer related. In the group of patients with aneuploid tumors, a significantly more frequent cause of death were distant metastases (78\% of deaths), and among patients with diploid tumors it was local recurrence (32\% of deaths) ( $p=0.0007$; Table II). Our analysis of the influence of single factors on survival included, apart from ploidy, age, gender, TNM stage, separately T-stage and N-stage, the degree of differentiation of cancer cells, the type of surgery, and postoperative oncological treatment. We did not find any significant correlation between survival prospects and age, gender, degree of differentiation of cancer cells, the type of surgery, or the adjuvant chemo- and/or radiotherapy. The differences in 10-year survival rates related to T-stage were statistically significant, while the proportion of survi-

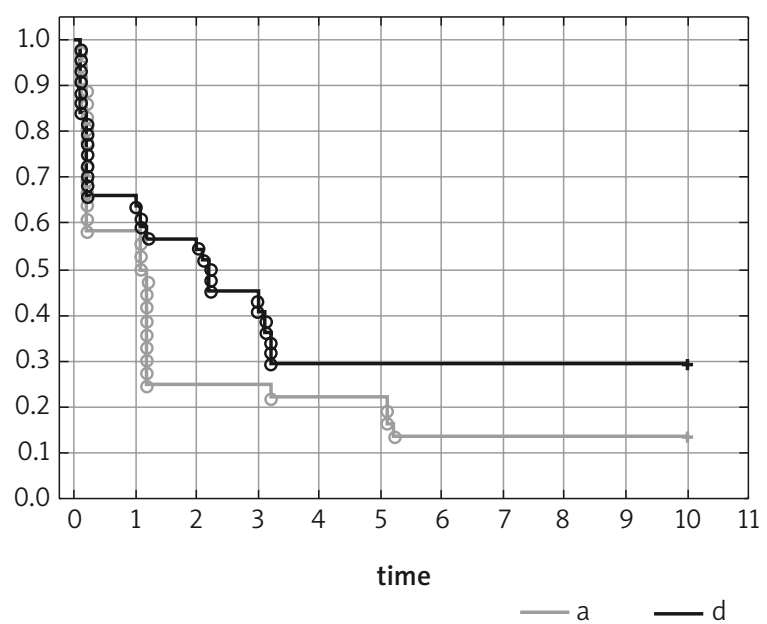

Fig. 1. Overall 10-year survival related to DNA ploidy (a - aneuploid tumors, $d$ - diploid tumors)
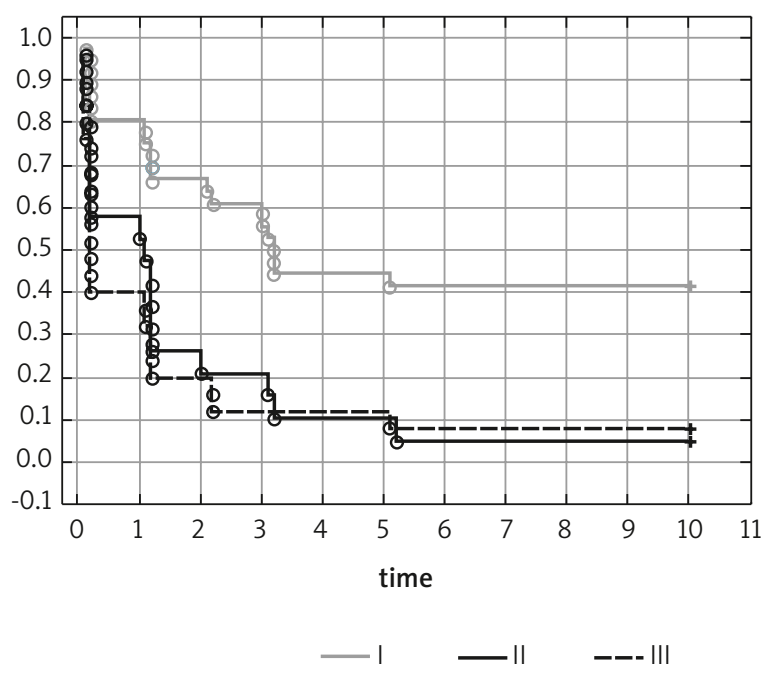

Fig. 3. Overall 10-year follow-up according to TNM stage vors was $40 \%$ for $\mathrm{T} 1$ stage, $34.4 \%$ for T2 stage, $11.1 \%$ for T3 stage, and $5.6 \%$ for T4 stage ( $p=0.028$; Fig. 2 ). A similarly significant relation between the survival expectancy and the stage of cancer progression according to the TNM classification was observed ( $p=0.0001$; Fig. 3). Substantial differences in survival expectancy were also observed in relation to the occurrence of metastases in regional lymph nodes, although these differences remained on the border of statistical significance (Fig. 4). The rate of 10-year survi-

Table II. Causes of death related to DNA ploidy

\begin{tabular}{lcccc} 
distant metastases & $\begin{array}{c}\text { Diploid } \\
\text { tumors }\end{array}$ & $\begin{array}{c}\text { Aneuploid } \\
\text { tumors }\end{array}$ & Total & $p$ \\
\hline local recurrence & $39 \%$ & $78 \%$ & $62 \%$ & $<0.05$ \\
\hline metastases + recurrence & $3 \%$ & $16 \%$ & $25.9 \%$ & $<0.05$ \\
\hline other causes & $26 \%$ & $0 \%$ & $6.2 \%$ & NS \\
\hline
\end{tabular}

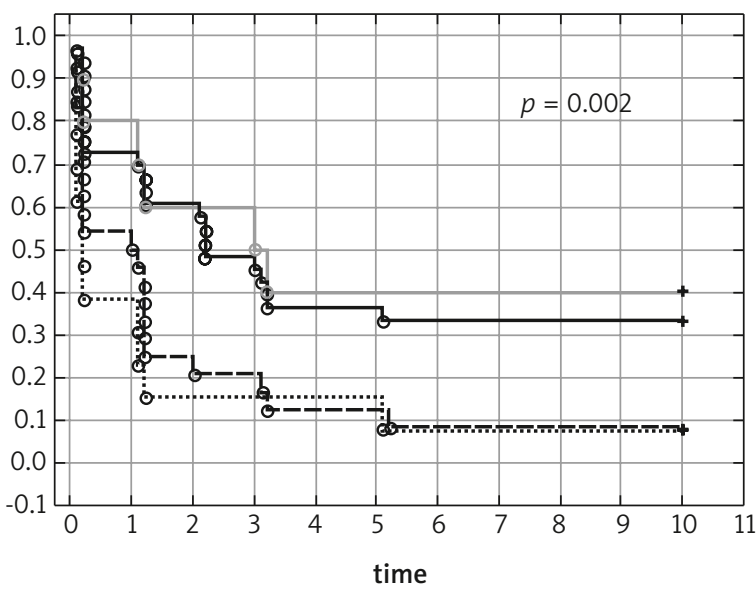

- $\mathrm{T} 1 \quad \mathrm{~T} 2 \quad--\mathrm{T} 3$

........ $T 4$

Fig. 2. Overall 10-year follow-up according to T-stage

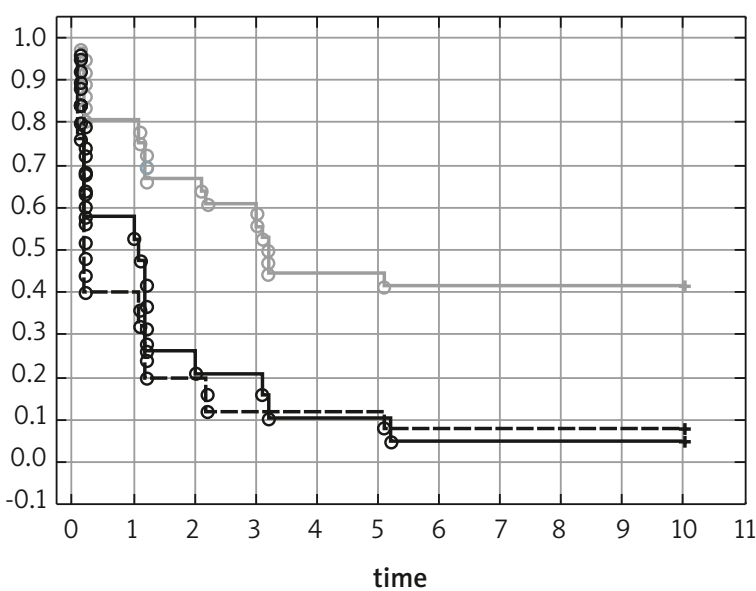

- group 1 -group 2 ---group 3

Fig. 4. Overall 10-year survival related to $\mathrm{N}$-stage (group 1 - stage NO; group 2 - stage N1; group 3 - stage N2) 
val in the NO group was $27.4 \%$, in the N1 group $20 \%$, and in the $\mathrm{N} 2$ group $0 \%(p=0.09)$. A multivariate regression analysis performed with Cox's method confirmed a significant influence of three factors on long-term survival prospects. These factors were the stage of cancer progression according to the TNM classification, T-stage, and DNA ploidy. The $\mathrm{N}$-stage was on the border of significance.

\section{Discussion}

Flow cytometry has been known for over 40 years and has attracted considerable interest among scientists researching the process of neoplasia. It is a method that is not only helpful in the diagnostics of pre-cancer conditions and malignant tumors, but also enables the researcher to obtain valuable information regarding the proliferation potential of the tumor. It allows for phenotype marking of the analyzed cells and carrying out measurements of nuclear DNA content. It offers a possibility of examining any number of cells at a great speed and with an accuracy allowing for the assessment of the changes in the DNA content at the rate of $2-3 \%[13,14]$. Abnormal DNA content in cancer cells indicates the genetic instability that is a characteristic feature of malignant tumors. It may be manifested in the form of epigenetic instability, resulting from abnormal DNA methylation and changes in the structure of histone proteins, as well as chromosome instability $[15,16]$. It is chromosome instability, consisting in the occurrence of an increased number of chromosome breaks, as well as structural and numerical aberrations (translocations, deletions, duplications, transversions), that is responsible for aneuploidy; it is also clearly related to an increased risk of developing neoplastic diseases $[17,18]$.

The discussion on the prognostic significance of ploidy in cancer cells has been ongoing since the early 1980s. The first publications were preoccupied mainly with colorectal carcinoma, breast carcinoma, ovarian carcinoma, and head and neck cancers [19-21]. Soon reports on DNA content abnormalities in lung cancer cells followed [2, 22]. The conclusions concerning research on the influence of aneuploidy on the long-term results of NSCLC surgical treatment, drawn by various authors, have been quite inconsistent. Some researchers believe that aneuploidy contributes to the recurrence of neoplasia and shortens the survival pe$\operatorname{riod}[3,4,9,23,24]$. Others refute the prognostic significance of ploidy [25-27] or claim that its influence on the clinical course concerns only squamous cell carcinoma [28, 29]. The differences of opinion on the prognostic significance of ploidy may have several underlying causes. Among them are the phenomenon of tumor heterogeneity, or the existence of diploid and aneuploid regions within a single tumor [23, 30], poor quality of material sampled for the cytometric analysis, resulting from the presence of stroma cells and tumor-infiltrating lymphocytes [25, 31], and non-uniform criteria of ploidy assessment used by various researchers [32]. Additional peaks on the histogram curve are an unquestionable indication of aneuploidy, although its existence may also be concluded from single, yet deformed or abnor- mally located G0/G1 peaks, the high value of the coefficient of variation (CV), as well as a significant number of cells at $\mathrm{S}$ or G2M phase of the cell cycle [32]. The CV coefficient reflects the relation between relative standard deviation (RSD) and the G0/G1 signal width at half-signal height and depends on the condition of the analyzed tissue. Its value increases as the result of autolysis or sample contamination and should not exceed $8 \%$ for paraffin specimens [31, 33]. In the analyzed material, all cases of the CV value $>8 \%$ were excluded or subjected to another examination, thus reaching the level of $\mathrm{CV}<8 \%$.

It is unquestionable that abnormal DNA content can be observed in the majority of tumors. The proportion of aneuploid tumors in the subject group was $44.5 \%$ and stayed within the limits suggested by various research works on paraffin specimens (31-84\%) [3, 8, 9, 23, 24]. No correlation between ploidy and the TNM stage or the degree of differentiation of cancer cells was observed in the analyzed material, although other authors pointed to the greater frequency of aneuploidy occurrence at stage III and IV of the disease $[6,27,34]$ and in poorly differentiated carcinomas (G3) $[8,24]$, as well as to a greater frequency of metastases in mediastinal lymph nodes in aneuploid tumors [6, 24]. Unfavorable late results of NSCLC surgical treatment are connected, above all, to a high death rate within the first 2-3 years after the surgery, the main cause of death being neoplastic dissemination. Within the subject group analyzed in the present research, $66 \%$ of patients died within 3 years after surgery, most of them as a result of distant metastases. It was also within the first three years after surgery that the most significant ploidy-related difference in survival rates $(46.5 \%$ in the case of diploid tumors and $25 \%$ in the case of aneuploid tumors) was observed. In the logistic regression model $(p=0.008)$, ploidy, together with the degree of clinical progression, remained a crucial survival factor, while affiliation to the aneuploid group lowered the chance of survival by three times $(\mathrm{Qr}=3.02,95 \%$, confidence interval 1.02-8.96). This difference was also clearly demonstrated in the analysis of 10 -year survival (30.2\% vs. $13.9 \%)$. What is interesting is that all deaths that occurred within 5 years after surgery concerned patients with aneuploid tumors. Contrary to diploid tumors, the cause of death in the vast majority of aneuploid cases were distant metastases (78\% of cases). The advantage of the present study is the relatively large subject group and the extensive period of observation. The existing literature contains only a few reports on ploidy-related 10-year survival rates, the authors of which confirm the prognostic significance of abnormal DNA content in endometrial carcinoma [35], breast carcinoma [36], or urinary bladder carcinoma patients [37]. In 2003 Gawrychowski et al. presented the analysis of a decade-long observation of 191 NSCLC patients, in which they stressed the significance of the percentage of S-phase cells as an independent prognostic factor. Five- and 10-year survival rates were lower, while disease-free survival (DFS) periods were shorter in aneuploid cases [8]. The largest population of squamous cell lung cancer patients treated 
surgically (207) has been analyzed by Kołodziejski, who confirmed a smaller probability of 2- and 5-year survival within the aneuploid group [9].

In compliance with the growing tendency of recent years to individualize the treatment of NSCLC, researchers have undertaken efforts to define as many potential factors influencing the course of the disease as possible. More and more attention is paid to molecular disorders in cancer cells, such as proto-oncogene activation or mutations of suppressor and mutator genes, in an attempt to determine the genetic profile connected with a high risk of recurrence of the disease after a radical surgical treatment. Although marking DNA content in cancer cells has not yet been introduced into standard clinical practice, it nevertheless seems a relatively easy test of assessing the proliferation activity of the tumor and could be useful in the qualification of patients for postoperative chemotherapy.

\section{Conclusions}

1. Flow cytometry enables a retrospective analysis of DNA content in cancer cells. The rate of aneuploid tumors in cases of squamous cell lung cancer is significant and amounts to $45 \%$.

2. Based on a 10-year observation period, it was ascertained that aneuploid patients treated surgically for squamous cell lung cancer show markedly worse late results of treatment. The most frequent cause of death in these cases are distant metastases.

3. The measurement of DNA content in patients with squamous cell lung cancer may, along with the standard prognostic factors, provide a useful method of qualifying patients for postoperative chemotherapy.

\section{This work has not been co-financed by any institution.}

\section{References}

1. Teodori L, Tirindelli-Danesi D, Mauro F, De Vita R, Uccelli R, Botti C, Modini C, Nervi C, Stipa S. Non-small cell lung carcinoma: tumor characterization on the basis of flow cytometrically determined cellular heterogeneity. Cytometry 1983; 4: 174-183.

2. ten Velde GP, Schutte B, Vermeulen A, Volovics A, Reynders MM, Blijham $\mathrm{GH}$. Flow cytometric analysis of DNA ploidy level in paraffin-embedded tissue of non-small cell lung cancer. Eur J Cancer Clin Oncol 1988; 24: 445-460.

3. Zimmerman PV, Hawson GA, Bint MH, Parsons PG. Ploidy as a prognostic determinant in surgically treated lung cancer. Lancet 1987; 5: 530-533.

4. Volm M, Hahn EW, Mattern J, Müller T, Vogt-Moykopf I, Weber E. Five years follow up study of independent clinical and flow cytometric prognostic factors for the survival of patients with non-small cell lung carcinoma. Cancer Res 1988; 48, 2923-2928.

5. Salvati F, Teodori L, Trinca ML, Pasquali-Lasagni R, Göhde W. The relevance of flow cytometric DNA content in the evaluation of lung cancer. J Cancer Res Clin Oncol 120: 233-239.

6. Ogawa J, Tsurumi T, Inoue H, Shohtsu A. Relationship between tumor DNA and regional lymph node changes in lung cancer. Cancer 1992; 69: 1688-1695.

7. Mugüerza JM, Díez M, Torres AJ, López-Asenjo JA, Picardo AL, Gómez A, Hernando F, Cayón R, Granell J, Balibrea JL. Prognostic value of flow cytometric DNA analysis in non-small cell lung cancer, rationale of sequential processing of frozen and paraffin embedded tissue. World J Surg 1997; 21: 323-329.

8. Gawrychowski J, Lackowska B, Gabriel A. Prognosis of the surgical treatment of patients with non-small cell lung cancer (NSCLC)-relation to DNA ploidy. Eur J Cardiothorac Surg 2003; 23: 870-877.
9. Kołodziejski L. Ploidalność DNA-nowy, niezależny czynnik prognostyczny w chirurgicznym leczeniu płaskonabłonkowego raka płuca. Pol Przegl Chir 1996; 68: 899-904.

10. Dyszkiewicz W, Kasprzyk M, Piwkowski C, Gasiorowski L. Prognostic significance of DNA ploidy in squamous cell lung carcinoma: is it really worth it? Ann Thorac Surg 2000; 70: 1629-1633.

11. Kasprzyk M, Dyszkiewicz W, Piwkowski C, Gasiorowski L, Kaczmarek E. Prognostic value of DNA ploidy: 5-year follow-up of patients with resectable squamous cell carcinoma (SCC) of the lung. Lung Cancer 2006; 51: 201-206.

12. Hedley DW, Friedlander ML, Taylor IW, Rugg CA, Musgrove EA. Method for analysis of cellular DNA content of paraffin-embedded pathological material using flow cytometry. J Histochem Cytochem 1983; 31: 1333-1335.

13. Obrębowska A, Spaczyński M. Cytometria DNA w diagnostyce onkologicznej. Wspolczesna Onkol 1997; 2: 13-15.

14. Auer G, Krommenwett M, Von Rosen A. DNA measurement- its value for diagnosis and prognosis. Anat Qant Cytol Hist 1989; 10: 90-94.

15. Kozłowska J, Łaczmańska I. Niestabilność genetyczna - jej znaczenie w procesie powstawania nowotworów oraz diagnostyka laboratoryjna. Nowotwory 2010; 6: 548-553.

16. Kordek R, Bartkowiak J. Niestabilność mikrosatelitarna w nowotworach człowieka. Onkol Pol 1999; 2: 109-112.

17. Boffetta P, van der Hel O, Norppa H, Fabianova E, Fucic A, Gundy S, Lazutka J, Cebulska-Wasilewska A, Puskailerova D, Znaor A, Kelecsenyi Z, Kurtinaitis J, Rachtan J, Forni A, Vermeulen R, Bonassi S. Chromosomal aberrations and cancer risk: results of a cohort study from Central Europe. Am J Epidemiol 2007; 165: 36-43.

18. Bonassi S, Norppa H, Ceppi M, Strömberg U, Vermeulen R, Znaor A, Cebulska-Wasilewska A, Fabianova E, Fucic A, Gundy S, Hansteen IL, Knudsen LE, Lazutka J, Rossner P, Sram RJ, Boffetta P. Chromosomal aberration frequency in lymphocytes predicts the risk of cancer: results from a pooled cohort study of 22358 subjects in 11 countries. Carcinogenesis 2008; 29: 1178-1183.

19. Friedlander ML, Hedley DW, Taylor IW. Clinical and biological significance of aneuploidy in human tumors. J Clin Pathol 1984; 37: 961-974.

20. Merkel DE, McGuire WL. Ploidy, proliferative activity and prognosis. DNA flow cytometry of solid tumors. Cancer 1990; 65: 1194-1205.

21. Nervi C, Badaracco G, Maisto A, Mauro F, Tirindelli-Danesi D, Starace G. Cytometric evidence of cytogenetic and proliferative heterogeneity of human solid tumors. Cytometry 1982; 2: 303-308.

22. Tirindelli-Danesi D, Teodori L, Mauro F, Modini C, Botti C, Cicconetti F, Stipa S. Prognostic significance of flow cytometry in lung cancer-a 5-year study. Cancer 1987; 60: 844-851.

23. Liewald F, Hatz R, Storck M, Orend KH, Weiss M, Wulf G, Valet G, SunderPlassmann L. Prognostic value of deoxyribonucleic acid aneuploidy in primary non-small cell lung carcinomas and their metastases. J Thorac Cardiovasc Surg 1992; 104: 1476-1482.

24. Maounis NF, Chorti M, Apostolakis E, Ellina E, Blana A, Aggelidou M, Dritsas I, Markidou S. Prognostic impact of deoxyribonucleic acid (DNA) image analysis cytometry and immunohistochemical expression of Ki67 in surgically resected non-small cell lung cancers. Cancer Detect Prev 2006; 30: 507-514.

25. Otsuka H, Funai S, Azumi T, Hara S, Okuno K, Yasutomi M. Ability of bivariate cytokeratin and deoxyribonucleic acid flow cytometry to determine the biologic aggressiveness of resectable non-small cell lung cancer. J Thorac Cardiovasc Surg 2002; 124: 293-298.

26. Carp NZ, Ellison DD, Brophy PF, Watts P, Chang MC, Keller SM. DNA content in correlation with postsurgical stage in non-small cell lung cancer. Ann Thorac Surg 1992; 53: 680-683.

27. van Bodegom PC, Baak JP, Stroet-van Galen C, Schipper NW, Wisse-Brekelmans EC, Vanderschueren RG, Wagenaar SS. The percentage of aneuploid cells is significantly correlated with survival in accurately staged patients with stage I resected squamous cell lung cancer and long-term follow-up. Cancer 1989; 63: 143-147.

28. Isobe H, Miyamoto H, Shimizu T, Haneda H, Hashimoto M, Inoue K, Mizuno S, Kawakami Y. Prognostic and therapeutic significance of the flow cytometric nuclear DNA content in non-small cell lung cancer. Cancer 1990; 65: 1391-1395.

29. Sahin AA, Ro JY, el-Naggar AK, Lee JS, Ayala AG, Teague K, Hong WK. Flow cytometric analysis of the DNA content of non-small cell lung cancer. Ploidy as a significant prognostic indicator in squamous cell carcinoma of the lung. Cancer 1990; 65: 530-537.

30. Carey FA, Lamb D, Bird CC. Intratumoral heterogeneity of DNA content in lung cancer. Cancer 1990; 65: 2266-2269. 
31. Shankey TV, Rabinovitch PS, Bagwell B, Bauer KD, Duque RE, Hedley DW, Mayall BH, Wheeless L, Cox C. Guidelines for implementation of clinical DNA cytometry. International Society for Analytical Cytology. Cytometry 1993; 14: 472-477.

32. Niezabitowski A, Lackowska B. Przydatność kliniczna oceny DNA przy użyciu cytometrii przepływowej w nowotworach ludzkich. Cent Eur J Immunol Supl 2, 1996,;147-155.

33. Krygier-Stojałowska A, Gontarewicz A, Grzegrzółka R, Gapski Z. Wybrane aspekty zasad przygotowania materiału komórkowego do przepływowej DNA cytometrii. Nowiny Lekarskie 1998; 67: 448-456.

34. Rice TW, Bauer TW, Gephardt GN, Medendorp SV, McLain DA, Kirby TJ. Prognostic significance of flow cytometry in non-small cell lung cancer. J Thorac Cardiovasc Surg 1993; 106: 210-217.

35. Susini T, Amunni G, Molino C, Carriero C, Rapi S, Branconi F, Marchionni M, Taddei G, Scarselli G. Ten-year results of a prospective study on the prognostic role of ploidy in endometrial carcinoma: DNA aneuploidy identifies high-risk cases among the so-called "low-risk" patients with well and moderately differentiated tumors. Cancer 2007; 109: 882-890.

36. Moureau-Zabotto L, Bouchet C, Cesari D, Uzan S, Lefranc JP, Antoine M, Genestie C, Deniaud-Alexandre E, Bernaudin JF, Touboul E, Fleury-Feith J. Combined flow cytometry determination of S-phase fraction and DNA ploidy is an independent prognostic factor in node-negative invasive breast carcinoma: review of a series of 271 patients with stage I and II breast cancer. Cancer Radiother 2005; 9: 575-586.

37. Cai T, Margallo E, Nesi G, Giubilei G, Rizzo M, Bartoletti R. Prognostic value of static cytometry in transitional cell carcinoma of the bladder: recurrence rate and survival in a group of patients at 10 years follow-up. Oncol Rep 2006; 15: 213-219. 